Professor Büttner continued to teach and to supervise Ph.D. students for several years after he reached the age of mandatory retirement in 2003. His hope was to return to his own research once he had secured the survival of his Chair. In the eyes of local decision makers, however, the fall of the Berlin wall in 1989 not only entailed new spending priorities aimed at unifying the country socially and economically, but also heralded the much celebrated "end of history" that would inevitably globalize supposedly backward places such as the Middle East and make them perfectly intelligible to any generalist. Thanks to Büttner's diplomatic perseverance, reason ultimately prevailed and in 2007 a successor was appointed.

Professor Büttner is survived by his wife, Inge Klostermeier-Büttner, his daughter, Nicole Fierek, and his two sons, Jan Mermin and Peter Büttner. \&o

Eberhard Kienle CNRS/Sciences-Po, Paris/Grenoble

Peter von Sivers Univerity of Utah

\title{
Katherine Payne Moseley
}

1941-2012

KATHERINe PAYNe MOSEley (K. P. MOSELEY) PASSED AWAY PEACEFUlly on 4 October 2012. Her often cited work with Immanuel Wallerstein on precapitalist social structures initiated a long list of studies and publications on the Trans-Saharan trade, the political economy of West Africa including Sierra Leone and Nigeria, and most recently the economic and social history of the larger oasis band of the northern Saharan edge including Morocco and Mauritania. Kay also actively promoted water and other environmental issues, as represented by her paper entitled "Development or Ecocide? Dilemmas of Water Exploitation in the Sahara." A Ph.D. in Sociology from Columbia University, she did her fieldwork in Dahomey and taught at Fourah Bay College (Sierra Leone) and at the University of Port Harcourt (Nigeria), as well as at Vanderbilt, Brooklyn College, the University of Connecticut-Storrs, and several other American universities. 
At Port Harcourt during the 1980 s, she is remembered for her contribution to building the Sociology Department, alongside Claude Ake, Pade Badru and Teresa Turner. Many of the current faculty are her former students; she is also renowned for her kindness to students. As Pade recalls:

While Kate was assigned the duty of building our graduate program, Teresa and I were to develop the Center for Energy Studies. Kate stayed away from the fractious politics of the department and focused her energy on teaching and developing our graduate program and financially supporting several local students who could not afford to pay their tuition. I was soon to discover Kate's love of the local culture and people, especially the Ijaw minority ethnic group of southeastern Nigeria. Kate made friends from all the various sections of the university community, especially our Creole colleagues from Sierra Leone, many of whom she had met while she was teaching at Fourah Bay College. Many visiting foreign professors, especially from Europe and America, would spend several days at Kate's house before going to other parts of the country where they had been hired to teach. Her door was always open to everyone, and the arrival of a new visitor would often be followed by an elaborate party for that weekend.

Almost every weekend, Kate would organize parties. Kate's favorite music at these parties was Igbo Highlife music from popular musicians like Eddie Okonta, Osita Osadebey, and the younger generation of Igbo musicians. And of course, Kate would make sure that she danced with every single person attending the party. In the end, she became our unofficial social secretary, and we would come up with any reason to get her to bring everyone together at her house, which she often left unlocked for friends and neighbors. As the military repression of academic freedom grew worse, I told Kate that it was time for us to leave Port Harcourt but she refused, telling me that she could not summon the courage to leave her students behind for a comfortable life in the States. At that time, Kate's house had been turned into some kind of "bush" canteen where poor or low-income students could come to have a meal.

She returned to the United States in the late 1980s. In the 1990s, Kay was a visiting professor at several U.S. universities punctuated by a two-year Fulbright Research Fellowship in Morocco at the Institut des Études Africaines, Rabat, where she studied Trans-Saharan aspects of commerce and exchange, formal and informal, past and present, continuing work begun in Mali and Niger. This resulted in the paper, "The Moroccan South, Oasis Social Structures, and 
the Trans-Saharan Trade," presented at the 1994 African Studies Association and "Sharecroppers, Serfs, and Notables: Variations in the Traditional Status of the Haratin," presented at al-Akhawayn University in 2000.

From 2000 to 2006 she worked as a Foreign Service Officer with the U.S. State Department and served in Sudan, Mauritania, and Chad. She continually returned to Mauritania to study the structures and sustainability of oases societies whose water sources are under threat. As one close friend described it:

Kay loved the research itself: traveling on her own to a small desert town and spending a few days with the people who lived there, asking questions and taking copious notes as she listened. Despite the heat, food, or anything else that most people might find a reason to complain about, I never once heard Kay complain about these logistical challenges. Although she was always thoroughly exhausted, Kay came back to Nouakchott ready to head to the library to continue her research or schedule meetings with various professors and academics to get their perspectives on her findings. Underlying Kay's research was a sense of urgency.

Family and friends will always remember her warmth, sense of fun, wit, love of jazz and African rhythms, and music in general, generosity, hospitality, openness and elegance. A colleague's vivid recollection sums up our feelings:

I will never forget my first year in Mauritania when I first saw Kay dancing Sabar at an Embassy $4^{\text {th }}$ of July party. I went to get a drink and came back to see an enormous circle around Kay as she leapt, kicked, and danced her way into the hearts of everyone present. Kay was 70 going on 25 years of age. I knew at that moment that I wanted to be just like her.

Rosemary Galli Independent Scholar 